\title{
The Use of a Consumer Survey to Determine the Relevant Market - Case Study for public transport between Prague and Most
}

\section{Eliška Kleinová1}

\begin{abstract}
The aim of this paper is to define a relevant market in the passenger transportation industry for the route between Prague and Most. A rising number of bus companies operating on this particular market suggests competition pressures. On the basis of European Commission legislation and its common practice we apply a demand-side substitution analysis in the form of the so called SSNIP test. Data for the empirical analysis were collected by means of a customer survey, which captured reactions to a $10 \%$ increase in the price of purchased tickets. The survey outcomes were then used to calculate an own price elasticity of demand and to carry out a critical loss analysis in order to define the relevant market.
\end{abstract}

Key words: Transport Economics, SSNIP test, Critical loss analysis, Consumer survey

JEL Classification: R40

Received: 17 June 2015 / Accepted: 12 October 2015 / Sent for Publication: 11 March 2016

\section{Introduction}

Modern competition policy nowadays makes use of economic perspectives more than ever before. The overwhelming majority of court decisions within this field are supported by elaborate economic analysis. This often includes, for instance, studies of relevant markets, which can be used to determine whether a certain company's behaviour is likely to constrain competition in a given industry, and to assess the degree of real competition on the market.

The aim of this paper is to define a relevant market on the basis of a self-designed consumer survey. The case chosen concerns the intercity passenger transport services connecting the city of Most in the north of the Czech Republic with the capital city Prague. This route was of particular interest due to the price politics established by the incumbent rail service provider - České dráhy (Czech Railways - ČD). Up to now, ČD is $100 \%$ state owned and holds more than $90 \%$ of the market share in rail passenger transport across the whole country. Even though the company claims to set its prices uniformly

\footnotetext{
${ }^{1}$ Department of Economics, Faculty of Economics and Administration, Masaryk University, Brno, Czech Republic. E-mail: eliska.klein@gmail.com
}

(C) 2016 by the authors; licensee Review of Economic Perspectives / Národohospodářský obzor, Masaryk University, Faculty of Economics and Administration, Brno, Czech Republic. This article is an open access article distributed under the terms and conditions of the Creative Commons Attribution 3.0 license, Attribution - Non Commercial - No Derivatives. 
according to distance travelled, with tariffs calculated according to the number of kilometers travelled, the reality is rather different. A single ticket from Prague to Teplice, a city situated on the same line, was more expensive than a single ticket from Prague to Most, which is 30 kilometers farther. This price difference was eliminated at the end of 2013 when $\breve{C D}$ changed its price politics. This can be seen in Table 1, which reports all ticket prices for bus and rail companies operating services on the route in question. However, this change had almost no impact on the results of our empirical analysis, as we will explain later. The second reason for choosing to focus on this particular route was increasing competition among the bus companies, like the entrance of Student Agency Company into this particular market in March 2013. Hence, this paper can support the economic analysis of competition in this area and help to define a relevant market in case of a competition infringement.

\section{Methodology}

Our basis for deciding which method would be the most suitable to define a relevant market was a set of tools commonly used by the Czech Office for Protection of Competition (ÚOHS), which proceeds from European Commission practice (European Commission, 1997). Of the various theoretical concepts available, we chose the method of demand-side substitution based on the so called SSNIP test, which examines whether a hypothetical monopolist could profitably and permanently increase prices by $5 \%-10 \%$ in a given candidate market (Motta, 2004; Alese, 2008; Kokkoris, 2010; Schwalbe \& Zimmer, 2009). The SSNIP test can be evaluated via either price analysis or critical loss analysis (ibid). Price analysis uses the key intuition that if two products are in the same relevant market then competition between them will be sufficiently strong to ensure the same movements to their product prices over time (Amelio and Donath, 2009). Price analysis can therefore support the SSNIP test outcomes, but does not provide a direct answer to the profitability question. On the other hand, critical loss analysis directly estimates whether a price increase of $5 \%-10 \%$ is profitable for a firm, by comparing the so-called critical loss with the actual loss suffered (Jones a Sufrin, 2008). In general, the hypothetical monopolist's profit equals the difference between the total revenues and costs. Since the fixed costs do not change with the amount of output produced, when the company decides whether to increase or decrease output it takes into account only the variable costs. Thus, if the company increases the product price, this action automatically increases its profits from products sold, however, at the same time it loses the profit from the products that are not sold due to the higher price. This statement can be written mathematically as:

$$
\left(P_{0}+\Delta P-M C\right)\left(Q_{0}+\Delta Q\right)=\left(P_{0}-M C\right) \Delta Q
$$

where $P_{0}$ is the initial price of the product, $\Delta P$ is the price increase $\left(\Delta P=P_{1}-P_{0}\right), M C$ are the constant marginal costs, $Q_{0}$ is an initial quantity demanded and $\Delta Q$ expresses a decline in quantity demanded, caused by the price increase $\left(\Delta Q=Q_{1}-Q_{0}\right)$. The critical loss is then defined as the maximum loss in sales resulting from a price increase that would still prove profitable. Both critical and actual loss can be expressed as follows:

$$
-\Delta Q / Q=X /(X+m)=\text { Critical Loss }
$$




$$
X * \varepsilon_{\text {own }}=\text { Actual Loss }
$$

where $X=\Delta P / P$ is the percentage increase in price, $m=(P-M C) / P$ is the initial price-cost margin defined as a gap between price and marginal cost, and $\varepsilon_{\text {own }}$ is own price elasticity. To express the critical loss by equation (2) requires a standard assumption that the hypothetical monopolist produces at constant marginal costs and that it faces a linear demand function (Hüschelrath, 2008). In reality the demand will never be exactly linear, but for small changes in price, departures from linearity should not normally cause large errors in calculating the change in profits (Farrell and Shapiro, 2008). Thus, we view the linear calculations as a reasonable approximation and use the general critical loss formula for our research. In order to acquire the data needed for calculating the actual loss, we carried out a customer survey, which captured the price sensibility of bus customers.

However, the results of the critical loss analysis may be biased due to the mistakes that commonly appear during the SSNIP test application. Possible problems include a 'toothless fallacy ${ }^{2}$ and the "cellophane effect's . To avoid the 'toothless fallacy the survey must focus only not on average customers but on marginal customers i.e. customers travelling on our examined route (Hüschelrath, 2008). Since the survey took place at bus stations, it was relatively easy to identify travellers who were going to the relevant destinations. Moreover, the sufficient competitive pressures in the examined market should guarantee an avoidance of the cellophane effect because transportation companies cannot afford to provide services at monopoly prices (Jones and Sufrin, 2008).

While applying the SSNIP test, we also had to deal with another significant complication: we were unable to estimate the hypothetical monopolist's margin, which is needed in order to calculate the revenues and thus the critical loss. Our conclusions therefore cannot be considered to provide an exact determination of the relevant market. However, using the consumer survey data, we were able to specify a critical margin defined as a boundary line from which the actual loss exceeds the critical loss and thus the ticket price increase would certainly be unprofitable for a hypothetical monopolist. As we show later, this conclusion is in line with the paper's aims.

\section{Characteristics of the transportation market}

The aim of this paper is to identify the relevant market for bus and train transportation on the route between Prague and Most. Both road and rail transport markets have similar characteristics in this case. According to the price policy operated by $\breve{C} D$ (valid until December 2013), the price of a single train ticket converged with that of a single bus ticket. This trend is captured in Table 1.

\footnotetext{
${ }^{2}$ Mistake of focusing on the behaviour of particular groups of consumers or on average consumers, in the process of defining relevant market.

${ }^{3}$ Mistake which occurs if the hypothetical monopolist is already charging monopoly profits, there is no further scope of any price rise. It would mean that the SSNIP may lead to a very wide market.
} 
It must be pointed out that after the price changes in December 2013 all train tariffs comparatively increased. Nevertheless, together with the increase in standard tariffs, ČD also made it permissible for students to combine a loyalty card discount with a student discount, which significantly lowered the price paid by student customers. The ticket price for a student travelling from Prague to Most (or vice versa) with a valid loyalty card became $95 \mathrm{CZK}$. The question of competitive prices is therefore still relevant for our research.

Table 1 Single adult ticket prices and discounted ticket prices for students aged under 15 years (St. -15) and over 15 years (St. 15+) from Prague to Most (in Czech crowns)

\begin{tabular}{l|ccc|ccc}
\hline & \multicolumn{3}{|c|}{ Standard Ticket } & \multicolumn{3}{c}{ Loyalty card } \\
Bus company & Adult & St. 15+ & St. 15 - & Adult & St. 15 + & St. 15 - \\
KAVKA & 100 & 75 & 37 & 95 & - & - \\
Catani & 100 & 75 & 37 & 95 & - & - \\
Karel Mudroch & 100 & 75 & 37 & - & - & - \\
Student Agency & 100 & 75 & 37 & 80 & 60 & 30 \\
DP city & 95 & 71 & 36 & 86 & - & - \\
Rail company & Adult & St. 15+ & St. 15 - & Adult & St. 15 + & St. 15 - \\
ČD (2013) & 105 & 63 & 39 & 95 & 57 & 35 \\
ČD (2014) & 210 & 127 & 79 & 158 & 95 & 59 \\
\hline
\end{tabular}

Source: passenger transport providers' websites

As far as travel time is concerned, the journey from Prague to Most by direct bus takes between 1 hour 20 minutes and 1 hour 50 minutes, while the same journey by direct train takes approximately 2 hours. There is therefore not any significant difference in the average journey time by each mode of transport, and the small difference would be easily discounted by customers who prefer the comfort of a train to the bus. The frequency and timetable of both types of transportation are very similar, with the greatest service provision during the morning and evening peak hours. As for quality, again both bus and train provide a very similar service. Although the Student Agency bus company offers additional services not provided by other companies, including free hot beverages, newspapers, magazines and the facility to watch films or TV on built-in touch screens. The offered services distinguish this company from the others.

\section{Empirical analysis - SSNIP test}

The first step in our analysis was to determine a candidate market. Despite the fact that the bus and train markets are very similar, it seemed that bus transportation was much more preferable for customers, as we had observed rising competition between the bus providers and the entry of new private bus companies into the market. It was therefore in our interest to ascertain whether customers consider train transport to be a relevant equivalent to bus transport, and thus examine whether the two types of transport togeth- 
er create one relevant market. Thus, bus transportation was chosen in our analysis as a candidate market.

\section{Critical loss estimate}

In order to compare the actual loss with the critical loss, we first needed to estimate the size of the latter variable. The formula for calculating the critical loss can be written as (1), as specified in section 2. While the size of $\mathrm{X}$, which represents the percentage change in price, is pre-set to $10 \%$, the margin size $m$ cannot be estimated in advance, as we mentioned above. Individual companies consider this factor to be a key trade secret, and are not willing to disclose it. Since the margin cannot be determined accurately by any other means, we instead created a table capturing all possible margin sizes and the related critical loss.

Table 2 Critical loss for a $10 \%$ price increase

\begin{tabular}{lllllllllll}
\hline Margin & $\mathbf{0 . 0 5}$ & $\mathbf{0 . 1}$ & $\mathbf{0 . 2}$ & $\mathbf{0 . 3}$ & $\mathbf{0 . 4}$ & $\mathbf{0 . 5}$ & $\mathbf{0 . 6}$ & $\mathbf{0 . 7}$ & $\mathbf{0 . 8}$ & 0.9 \\
Critical loss & 0.67 & 0.50 & 0.33 & 0.25 & 0.20 & 0.17 & 0.14 & 0.13 & 0.11 & 0.10 \\
\hline
\end{tabular}

Source: own calculation

\section{Actual loss estimate - customer survey}

The consumer survey took place over five subsequent days, from Thursday $6^{\text {th }}$ March to Monday $10^{\text {th }}$ March 2014. In total 380 passengers were directly interviewed while they were waiting for a bus at certain stations on the route in question (the survey covered all main stations at the start and end points for the route, namely Prague - Ládví, Prague Dejvice, Prague - Florenc and Most -1 . náměstí). To ensure the continuity of the data collection, respondents were surveyed during the daily and weekly peak and off-peak hours. The most important question in the survey identified the passengers' reactions to a hypothetical $10 \%$ price increase for a standard single ticket with their bus company; respondents had to choose one of the following five possible reactions:

1) I would still travel with the same bus company,

2) I would use another bus company,

3) I would travel by train,

4) I would travel by car,

5) I would not travel at all.

Table 3 summarizes the respondents' reactions (where numbers $1-5$ represent the answers above, in the order given). Even though the same number of buses from every company were included in the survey, the number of respondents who were travelling with each company differs significantly. This fact can be explained by the different vehicles' capacity. For example, Karel Mudroch bus company offers a special minibus service, which is more flexible and quicker, but carries just 8 people, compared with the 61 seats available on a Student Agency bus. 
Table 3 Number of responses divided by bus company

\begin{tabular}{ccccccc}
\hline Responses & Total & SA & Mudroch & Kavka & DP city & Catani \\
\hline 1 & 286 & 144 & 41 & 54 & 12 & 35 \\
2 & 73 & 17 & 7 & 26 & 8 & 15 \\
3 & 12 & 5 & 1 & 5 & 0 & 1 \\
4 & 8 & 2 & 1 & 2 & 1 & 2 \\
5 & 1 & 0 & 0 & 1 & 0 & 0 \\
Total & $\mathbf{3 8 0}$ & $\mathbf{1 6 8}$ & $\mathbf{5 0}$ & $\mathbf{8 8}$ & $\mathbf{2 1}$ & $\mathbf{5 3}$
\end{tabular}

Source: own calculation

From Table 3 we can easily calculate the total number of people who chose options 3,4 or 5 (travel by train, travel by car or not travel at all): only 21 out of 380 respondents would have chosen an alternative type of transportation or stayed home if the price of their bus ticket rose by $10 \%$. The overall elasticity can therefore be calculated using the following formula:

$$
\varepsilon_{\text {own }}=\frac{\Delta Q}{\Delta P}=\frac{\frac{21}{380} * 100}{10} \doteq 0.5526
$$

where $\Delta Q$ is the percentage change in quantity demanded and $\Delta P$ is the percentage price change.

Table 4 Number of travelers according ticket type and final weighted elasticity

\begin{tabular}{lrrrrrr}
\hline Ticket type & $\begin{array}{c}\text { N. of travel- } \\
\text { ers }\end{array}$ & $\begin{array}{c}\text { N. of reac- } \\
\text { tions 3-5 }\end{array}$ & Actual loss & $\begin{array}{c}\text { Sum of } \\
\text { money paid }\end{array}$ & Weight & $\begin{array}{c}\text { Weighted } \\
\text { elasticity }\end{array}$ \\
\hline Adult & 217 & 16 & $7.37 \%$ & 1329200 & 0.45 & $0.33 \%$ \\
LC Adult & 81 & 3 & $3.70 \%$ & 920835 & 0.31 & $0.11 \%$ \\
St. 15+ & 38 & 1 & $2.63 \%$ & 328575 & 0.11 & $0.03 \%$ \\
LC St. 15+ & 37 & 1 & $2.70 \%$ & 383880 & 0.13 & $0.03 \%$ \\
St. 15- & 3 & 0 & $0 \%$ & 2035 & 0 & $0 \%$ \\
LC St. 15- & 1 & 0 & $0 \%$ & 1560 & 0 & $0 \%$ \\
\hline
\end{tabular}

* LC = loyalty card

Source: own calculation

The resulting elasticity is $0.5526 \%$. Since the elasticity value is lower than 1 , we can conclude that the demand is highly inelastic. However, the aggregate elasticity does not reflect any other characteristics of the respondents. We assume that respondents who spend more money on transportation or use transportation more often should have a higher weight in the overall elasticity measure. For this purpose we followed the methodology of average weighted elasticity adopted by Rederer (2012) and Pečinka (2013) and created a new table, which records the actual loss according to the type of ticket 
purchased. The resulting elasticity thus reflects two factors: the frequency of travel to the examined destination, and the price paid for the ticket. The weighted coefficient is then the total sum of money paid by the respondent for one calendar year's travel. The results are reported in Table 4.

The arithmetic mean can be determined according to this formula (Souček, 2006):

$$
\bar{x}=\frac{\sum_{i=1}^{n} x_{i} n}{\sum_{i=1}^{k} n_{i}}
$$

where $n_{1}, n_{2}, \ldots n_{k}$ are the counted weights.

The resulting weighted elasticity calculated as the sum of the weighted elasticities for every ticket type is $0.51 \%$. This result does not vary significantly from the original total elasticity, but is more accurate. Finally we proceeded to calculate the actual loss by substituting the weighted elasticity value into the formula for actual loss:

$$
\begin{gathered}
A Z=X * \varepsilon_{\text {own }} \\
A Z=10 * 0,51=5.1 \% .
\end{gathered}
$$

The actual loss in case of $10 \%$ price increase is thus $5.1 \%$. If exactly 100 people choose to travel by bus, after a $10 \%$ price increase only five of them would switch to alternative transport, or not travel. Comparing the actual loss with the critical loss shown in Table 2, it is apparent that even if the bus companies' margins were greater than $90 \%$, the actual loss would still not exceed the critical loss. Thus a $10 \%$ price increase would be profitable for a hypothetical monopolist. Even though the exact margin data are not available, we can conclude that bus transportation constitutes a separate relevant market. At this point we can also confirm that the price elasticity is so small that ČD's change in price politics at the end of 2013 does not have any impact on our findings. One of the questions in the consumer survey asked respondents whether they knew the approximate price of a train ticket to the same destination; only a minority of the respondents knew the price to within $+/-10 \%$ accuracy, which is proof that most respondents did not consider these two types of transport as equivalent.

\section{Price sensibility}

Our previous assumption that the train and bus are equivalents for travel between Prague and Most was not confirmed by the outcomes of our analysis. Therefore, in this section we examine the factors that might affect the inelastic demand for bus transportation.

Data obtained from a consumer survey can be used to carry out a simple econometric analysis identifying price-sensitive and price-insensitive respondents. Using Gretl software we created a binary logit model in which the dependent variable - response - had two alternatives:

- 1 - in the case of a10\% price increase, the respondent does not switch to an alternative and uses the same bus company

- $\quad 0$ - in the case of a $10 \%$ price increase, the respondent switches to an alternative type of transportation (train, car) 
A list of the independent variables used in the model is provided in Appendix A. The first step in the analysis was to verify the significance of all independent variables. If the p-value was higher than 0.10 , this implied that the given variable was statistically insignificant.

Table 5 Logit model - 380 observations with dependent variable 'response'

\begin{tabular}{llllll}
\hline & Coefficient & Std. error & Slope & P-value & \\
\hline const & 0.793276 & 0.22888 & & 0.00053 & $* * *$ \\
Student_Agency & 0.847979 & 0.280868 & 0.148724 & 0.00254 & $* * *$ \\
daily commuting & -0.231348 & 0.475086 & - & 0.62629 & \\
obligation & -0.516105 & 0.270145 & -0.0908117 & 0.05607 & $*$ \\
student & 0.158761 & 0.334382 & 0.130057 & 0.63494 & \\
preference & 0.773774 & 0.272719 & - & 0.00455 & $* *$ \\
train & -0.145001 & 0.253291 & - & 0.56701 & \\
\hline
\end{tabular}

Number of cases 'correctly predicted' $=287(75.5 \%)$

Source: own calculation

According to Table 5, three insignificant variables were included in the model - train, student and daily commuting with very high p-value. Therefore, knowledge of the train ticket price, a daily commuting habit or the fact that the respondent was a student had no effect on the dependent variable. This outcome is quite interesting, since students and everyday passengers were assumed to be more price sensitive. The variable obligation (which captured the fact that the respondent was travelling to work or to school) seemed to be statistically significant at the $10 \%$ significance level. Two other factors preferences (respondent stated some preferred company) and Student Agency (respondent went with SA) - were statistically significant at the $1 \%$ significance level. The model can be generally evaluated by the number of cases correctly predicted, which is $75.5 \%$, and can be thus regarded to have relatively good prediction ability.

For a binary model we cannot use a conventional interpretation of marginal influence as in the case of a simple regression model. Nevertheless, we can interpret the sign of the coefficients and slopes. Both variables Student_Agency and preference have a positive sign, indicating that they are directly proportional with the dependent variable response. Thus the fact that the respondent travelled with the Student Agency bus company or had some preference as to which company they travelled with, increased the probability that he would not switch to an alternative in case of a $10 \%$ price increase. Conversely, the slope for the variable obligation is negative, indicating an inverse relationship - if the respondent was travelling to work or school, the probability that he would choose the same bus company despite a $10 \%$ price increase was reduced.

\section{Relevant market for Student Agency Company}

Both of the factors that proved to be statistically significant are in a manner of speaking connected to the Student Agency company (SA). The preferences variable largely refers to SA, because the majority of respondents who stated that they prefer a particular company preferred the Student Agency. This implies that price-insensitive customers who 
preferred SA had the biggest influence on the outcome of our analysis. In this respect the consumer survey enables us to assess the demand elasticity for this particular bus operator and create at least a brief outline of the relevant market determination.

The representative sample size for passengers using Student Agency services was 168 respondents. Table 6 captures their reactions to a hypothetical $10 \%$ ticket price increase.

Table 6 Number of responses and actual loss for SA company

\begin{tabular}{ccc}
\hline Response & N. of reactions & Actual loss \\
\hline 1 & 144 & $85.71 \%$ \\
2 & 17 & $10.12 \%$ \\
3 & 5 & $2.98 \%$ \\
4 & 2 & $1.19 \%$ \\
5 & 0 & $0.00 \%$ \\
\hline
\end{tabular}

Source: own calculation

If we substitute the total sum of reactions 2-5 (in this case we are also interested in reaction number 2 - choosing another bus company) into the formula for calculating the SA's own elasticity, we get:

$$
\varepsilon_{\text {own }}=\frac{\frac{24}{168} * 100}{10} \doteq 1.429
$$

The own demand elasticity for SA is $1.429 \%$ and the derived actual loss is $14.29 \%$. In other words, over $14 \%$ of passengers would have switched to a competitor or used another type of transportation in reaction to a $10 \%$ price increase. As in the previous model, it would be more accurate to apply weighted elasticity to this model. For this purpose, Table 7 captures reactions $2-5$ sorted for each ticket category (as in section 4.2). The weighted elasticity factor is then calculated as the sum of money paid for each ticket type out of the overall sum of money paid for all tickets together.

Table 7 Respondents travelling on SA company services by purchased ticket type, and the final weighted elasticity

\begin{tabular}{lrrrrrr}
\hline \multicolumn{1}{c}{ Ticket type } & $\begin{array}{c}\text { N. of travel- } \\
\text { ers }\end{array}$ & $\begin{array}{c}\text { N. of reac- } \\
\text { tions 2-5 }\end{array}$ & Actual loss & $\begin{array}{c}\text { Sum of } \\
\text { money paid }\end{array}$ & Weight & $\begin{array}{c}\text { Weighted } \\
\text { elasticity }\end{array}$ \\
\hline Adult & 59 & 14 & $23.73 \%$ & 227600 & 0.19 & $0.45 \%$ \\
LC Adult & 62 & 5 & $8.06 \%$ & 531335 & 0.45 & $0.36 \%$ \\
St. 15+ & 11 & 3 & $27.27 \%$ & 89925 & 0.08 & $0.21 \%$ \\
LC St. 15+ & 33 & 2 & $6.06 \%$ & 340200 & 0.29 & $0.17 \%$ \\
St. 15- & 1 & 0 & $0.00 \%$ & 74 & 0.00 & $0.00 \%$ \\
LC St. 15- & 1 & 0 & $0.00 \%$ & 1560 & 0.00 & $0.00 \%$ \\
\hline
\end{tabular}

* $L C=$ Loyalty card

Source: own calculation 
After summation of all the weighted elasticities we obtain a final elasticity of $1.19 \%$ (the actual loss is therefore almost $12 \%$ ). If we compare this actual loss with the critical loss, we can see that the SA company's margin would need to be at least $80 \%$ for the actual loss to exceed the critical loss in this case. If we assume that the company's margin is smaller than $80 \%$, which is a reasonable assumption, then a $10 \%$ price increase would be profitable for SA. Nevertheless, this evidence that the SA company is not currently operating at profit-maximizing level does not automatically imply that SA creates its own relevant market, in the sense of our previous findings. The low demand elasticity and actual loss may suggest that there is a new candidate market based on the company's different service characteristics, notably the higher quality of service provided, as mentioned in section 3. In this market, SA could increase its prices profitably because a sufficient number of customers would not switch to any other bus or train companies that offer a lower quality of service. Therefore SA is able to create a separate candidate market, as a high-quality bus service, in which the company is in a monopolistic position. If this is the case, and SA already has a monopoly, then our survey findings may be misleading due to the cellophane fallacy. However, since the company has so far set its prices in accordance with the prices of other competing bus companies (with standard quality of service provision), the cellophane fallacy, if applicable, would not be very acute.

\section{Conclusion}

This paper shows how the economic perspective can be used in the field of competition policy, namely in determining the relevant market and assessing demand elasticity. Based on consumer survey data, we established that bus companies operating between Prague and Most operate within a separate relevant market, which is not the same market as train transport providers between the same cities. Although we had originally assumed that the very similar characteristics of bus and train transport services would create strong competition pressures between the two transport modes, the price elasticity proved to be very small, corresponding with highly price-insensitive customers travelling by bus on this route. Even though we did not have exact margin values at our disposal, we were able to firmly conclude that the actual loss was so small that the relevant market is defined separately for bus service operators in this case.

The existence of so many highly price-insensitive customers was surprising and led us to include a binary logit model in our analysis, to identify the factors causing this phenomenon. This econometric model demonstrated that the most significant variables reflected a large number of respondents' preference for travelling with the Student Agency company. As a result, we assessed the demand elasticity and critical loss analysis separately for this particular company. Our findings were not as accurate as the relevant market determination for the overall transportation sector, since the data set was not sufficient enough. The price demand elasticity for SA is higher than 1, but the actual loss is still too small to easily exceed the critical loss. This implies that the SA company has not currently set its ticket prices at profit-maximizing level. Taking into account the different characteristics of the service provided, these findings suggest that SA may be in a monopolistic position and could create its own candidate market as a high-quality bus service. The next step in this research could be therefore a supply-side analysis, 
which should be taken into account in those situations when the suppliers are able to switch production to the relevant products and market them in the short term without incurring significant additional costs or risks in response to small and permanent changes in relative prices (EU Commission, 1997). Although, the application of a supply-side substitution is beyond the scope of this article, it can be considered as an appropriate further extension of this research.

Disclosure statement: No potential conflict of interest was reported by the author.

\section{References}

ALESE, F. (2008) Federal antitrust and EC competition law analysis. Burlington, VT: Ashgate Pub, xii, 544 p. ISBN 978-075-4670-100.

AMELIO, A. and DONATH, D. (2009) Market definition in recent EC merger investigations: The role of empirical analysis. Law \& Economics. Available at: www.ec.europa.eu/dgs/competition/economist/merger_investigations.pdf

CSI Market (2014). Transport and Logistics Industry. Profitability Information \& Trends. Available at: http://csimarket.com/Industry/industry_Profitability_Ratios.php?ind=1101

EU Commission (1997). Commission Notice on the definition of relevant market for the purposes of Community competition law. EUR-lex. Official Journal C 372.

FARELL, J. and SHAPIRO, C. (2008) Improving Critical Loss Analysis. The antitrust Source. Available here: http://faculty.haas.berkeley.edu/shapiro/critical2008.pdf

HÜSCHELRATH, K. (2008) Competition Policy Analysis: An Integrated Approach. ZEW Economic Studies. Springer Science \& Business Media 530 p. ISBN 3790820903

INC (2014). Financial report - transportation and warehousing. Available here: www.inc.com/quarterly-financial-report/transportation-and-warehousing.html

JONES, A. and SUFRIN, B. (2008) EC competition law: text, cases. 3rd ed. Oxford: Oxford University Press. ISBN 0199299048.

KOKKORIS, I. (2010) Merger control in Europe: the gap in the ECMR and national merger legislations. New York: Routledge, xxii, 293 p. ISBN 978-020-3846-728.

MOTTA, M. (2004) Competition policy: theory and practice. New York: Cambridge University Press, xxiii, 616 p. ISBN 05-210-1691-6.

NĚMEC, D. (2012) Základy ekonometrie. Brno: Masarykova univerzita, $304 \mathrm{~s}$.

PEČINKA, P. (2013) The use of SSNIP test to determine the relevant market in public transport on the destination Prague - Vienna. Diploma thesis. Masarykova univerzita Brno.

REDERER, V. (2012) Vymezování relevantního trhu a aplikace SSNIP testu v odvětví železniční dopravy. Diploma thesis. Masarykova univerzita Brno. 
SCHWALBE, U., ZIMMER, D. (2009) Law and economics in European merger control. New York: Oxford University Press, xxv, 449 p. ISBN 9780199571819

SOUČEK, E. (2006) Statistika pro ekonomy. Vyd. 1. Praha: Vysoká škola ekonomie a managementu, 267 s. ISBN 80-867-3006-9.

\section{Appendix A}

List of independent variables:

- Student_Agency:

1 - respondent intended to travel with Student Agency company

0 - respondent did not intend to travel with Student Agency company

- Daily commuting:

1 - respondent travelled on the given route on a daily basis

0 - respondent did not travel on the given route on a daily basis

- Obligation:

1 - respondent was travelling to work or school

0 - respondent was travelling for leisure purposes

- Student:

1 - respondent had applied a student discount

0 - respondent had not applied a student discount

- Preference:

1 - respondent favoured one particular company

0 - respondent did not have any preference as to which company to travel with

- Train:

1 - respondent knew the price of an equivalent train ticket

0 - respondent did not know the price of an equivalent train ticket 